\title{
Synthesis of $\mathrm{NiO} / \mathrm{SnO}_{2}$ Nanowires for Energy Applications
}

\author{
H. KAYA* \\ Malatya Turgut Ozal University, Faculty of Engineering and Natural Sciences, \\ Department of Engineering Basic Sciences, Malatya 44210, Turkey
}

\begin{abstract}
In this study, $\mathrm{SnO}_{2}$ nanowire arrays with lengths in the micrometres range were successfully synthesised by using polyethylene glycol (PEG) at room temperature. Then $\mathrm{Ni}$ was coated onto the $\mathrm{SnO}_{2}$ nanowires by chemical precipitation. These nanowires were heat-treated at $360,450,500$, and $650{ }^{\circ} \mathrm{C}$ to form various phases. X-ray powder diffraction studies showed that the heat-treated sample at $500{ }^{\circ} \mathrm{C}$ has a tetragonal rutile $\mathrm{SnO}_{2}$ phase. The Brunauer-Emmett-Teller surface area of the untreated $\mathrm{Sn}(\mathrm{COO})_{2}$ nanowires was determined as $5.74 \mathrm{~m}^{2} / \mathrm{g}$. After $\mathrm{Ni}$ coating and heat treatment at $360,450,500$, and $650^{\circ} \mathrm{C}$, the surface areas of the $\mathrm{NiO} / \mathrm{SnO}_{2}$ nanowires were measured to be $79.75,33.38,29.15$, and $21.13 \mathrm{~m}^{2} / \mathrm{g}$, respectively.
\end{abstract}

DOI: 10.12693/APhysPolA.137.404

PACS/topics: $\mathrm{SnO}_{2}$ nanowires, NiO-coated $\mathrm{SnO}_{2}$ nanowires $\left(\mathrm{NiO} / \mathrm{SnO}_{2}\right)$, supercapacitor, electrode, energy storage, PEG

\section{Introduction}

The need for energy increases proportionally with the development of technology. The energy we use at present is mainly provided by fossil fuels, which is highly damaging to the environment. Furthermore, studies have shown that fossil fuel use increases the formation of greenhouse gasses and thus, directly affects global warming. It is a fact, accepted by everyone, that eco-friendly energy sources are needed to minimise the consumption of fossil fuels. Recent studies have focused on the development of new products that may meet the energy requirements of devices in daily life, in addition to renewable energy sources. Supercapacitors stand out with their fast charge-discharge rate, excellent stability, long cycle life, and very high-power density in the energy storage field, compared to other energy storage devices [1-10]. Nanostructured materials are very impressive in the energy field as well as in other areas of technology due to their unique properties. Nanomaterials produced in different sizes and shapes have been used as an electrode material in supercapacitors. Besides the surface properties of the nanomaterial (nanowire, nanotube, nanoparticle, or nanoflake) which is used as an electrode, its type (such as carbon and derivatives, metal oxides, conductive polymers) is also another parameter that affects the performance of the supercapacitor. Metal oxide structures such as $\mathrm{RuO}_{2}, \mathrm{IrO}_{2}, \mathrm{MnO}_{2}, \mathrm{NiO}, \mathrm{Co}_{2} \mathrm{O}_{3}, \mathrm{Co}_{3} \mathrm{O}_{4}, \mathrm{~V}_{2} \mathrm{O}_{5}$, and $\mathrm{MoO}_{x}$ [11-27] have been extensively studied in this area. Of these, ruthenium oxide is the most promising electrode material due to its high specific capacitance, high electrical conductivity, long cycle life, and good electrochemical reversibility. However, it is highly toxic and costly [27]. Efforts to develop new products in the field of energy have begun with the aim of reducing the high

*corresponding author; e-mail: harun.kaya@ozal.edu.tr costs and the damage to nature. $\mathrm{SnO}_{2}$, an $n$-type semiconductor with a bandwidth of $3.6 \mathrm{eV}$, is extremely costeffective and eco-friendly [28, 29]. Only the $\mathrm{SnO}$ and $\mathrm{SnO}_{2}$ phases are stable in the tin-oxide binary system that has various oxide phases [30]. Additionally, $\mathrm{SnO}_{2}$ has applications in many areas of technology such as gas sensors, optoelectronic devices, magnetic recording, and magnetic resonance imaging systems [28-39]. The use of $\mathrm{Sn}$, and Sn-based elements, in Na-ion, Li-ion batteries, and supercapacitors have recently been investigated [40]. It is suggested that the capacitance value of the pure $\mathrm{SnO}_{2}$ structure is relatively low compared to some transition metal oxides. Ren et al. [41] obtained a specific capacitance value of $13.85 \mathrm{~F} / \mathrm{g}$ at a scanning speed of $10 \mathrm{mV} / \mathrm{s}$ on an electrode made of $\mathrm{SnO}_{2}$ microspheres. They coated the $\mathrm{SnO}_{2}$ microspheres with carbon and increased the specific capacitance value to $43.3 \mathrm{~F} / \mathrm{g}$.

In this study, firstly, $\mathrm{NiO}$ was coated onto $\mathrm{SnO}_{2}$ nanowires which were produced both cheaply and quickly. $\mathrm{NiO}$ was added to the structure to increase the relatively low specific capacitance of the $\mathrm{SnO}_{2}$ nanowires.

\section{Experimental}

The steps followed in the production of nanowires containing $\mathrm{Sn}$ and $\mathrm{Sn}-\mathrm{Ni}$ are outlined below. In the first step where $\mathrm{SnO}_{2}$ nanowire production process is given, $150 \mathrm{ml}$ of oxalic acid was completely dissolved in a mixture of $5 \mathrm{ml}$ pure ethanol and $20 \mathrm{ml}$ PEG $(\mathrm{MW}=600)$. When the oxalic acid was completely dissolved, $35 \mathrm{mM}$ $\mathrm{SnCl}_{2} \cdot 2 \mathrm{H}_{2} \mathrm{O}$ was added to the solution. After the complete dissolution of the $\mathrm{SnCl}_{2} \cdot 2 \mathrm{H}_{2} \mathrm{O}$ in solution, distilled water was added to the solution until a white precipitate formed and this was stirred for about $30 \mathrm{~min}$. The solution was then washed twice, with distilled water and ethanol, and centrifuged at $9000 \mathrm{rpm}$ for $15 \mathrm{~min}$. The washed precipitate was dried in a vacuum oven at $60^{\circ} \mathrm{C}$ for $24 \mathrm{~h}$. The dried precipitate was heat-treated at $500^{\circ} \mathrm{C}$ for $2 \mathrm{~h}$ at a rate of $1^{\circ} \mathrm{C} / \mathrm{min}$. 
In the second step where $\mathrm{Ni}$ coating process to produced $\mathrm{SnO}_{2}$ nanowires is given, $\mathrm{Sn}$ containing nanowires (about $0.1 \mathrm{~g}$ ) were added to $50 \mathrm{ml}$ of $50 \mathrm{mM} \mathrm{NiCl} \mathrm{mo}_{2}$ lution and stirred with a magnetic stirrer for one hour. Thereafter, $50 \mathrm{ml}$ of $50 \mathrm{mM} \mathrm{NH} \mathrm{m}_{4} \mathrm{OH}$ solution was added dropwise to this mixture at a rate of $1 \mathrm{ml} / \mathrm{min}$ and stirred with a magnetic stirrer at room temperature for $20 \mathrm{~h}$. The $\mathrm{NH}_{4} \mathrm{OH}$ dropping was performed with a "876 Dosimat Plus" automatic burette. After $20 \mathrm{~h}$, the resulting solution was washed twice with distilled water and ethanol and centrifuged at $9000 \mathrm{rpm}$ for $15 \mathrm{~min}$. The washed precipitate was dried at $60^{\circ} \mathrm{C}$ in a vacuum oven for $24 \mathrm{~h}$. The nanowires containing Ni/Sn were subjected to heat treatment at $360,450,500$, and $650^{\circ} \mathrm{C}$ in an air environment using a linear temperature gradient tube furnace.

In the final step, where formation of electrode is given, $75 \%$ active material $\left(\mathrm{SnO}_{2}\right.$ or $\left.\mathrm{SnO}_{2} / \mathrm{NiO} \mathrm{NWs}\right)$ and $15 \%$ acetylene black were ground and mixed in a $\mathrm{Zr}_{2} \mathrm{O}_{3}$ mortar for a certain time. Then $10 \%$ PVDF was added and this mixture was ground for one hour. A few drops of 1-methyl-2-pyrrolidinone were added into the homogeneous mixture and slurried. This slurry was dropped to spread over previously cleaned $\mathrm{Ni}$ foam. The resulting structure was dried in a vacuum oven at $60^{\circ} \mathrm{C}$ for $24 \mathrm{~h}$ and then pressed under a pressure of 5 tons. Electrochemical measurements were performed using a $6 \mathrm{M}$ $\mathrm{KOH}$ solution. Measurements were performed in an electrochemical cell consisting of a working electrode, platinum electrode, and an $\mathrm{Ag} / \mathrm{AgCl}$ reference electrode. The cyclic voltammetry (CV), charge-discharge, and electrochemical impedance spectroscopy (EIS) measurements of the electrode were performed using a Gamry Reference 3000 potentiostat/galvanostat/ZRA instrument. The surface properties of the $\mathrm{SnO}_{2}, \mathrm{NiO} / \mathrm{SnO}_{2}$ nanowires were investigated by using an FEI Nova Nano SEM 450 scanning electron microscope and thermogravimetric analyses (TGA) were carried out using a Shimadzu TGA-50 thermogravimetric analyser. The Brunauer-Emmett-Teller (BET) surface area, average pore diameter, and pore volume of the $\mathrm{SnO}_{2}, \mathrm{NiO} / \mathrm{SnO}_{2}$ nanowires were determined using a Micromeritics Gemini VII 2390t instrument. X-ray diffraction (XRD) measurements were made using the Rigaku-RADB brand X-ray diffractometer.

\section{Results and discussions}

In Fig. 1 the TGA thermograms of the Sn nanowires and $\mathrm{Ni} / \mathrm{SnO}_{2}$ nanowires formed using PEG are shown. TGA measurements were carried out in an air environment at a rate of $10^{\circ} \mathrm{C} / \mathrm{min}$. The TGA graph of the Sn nanowires produced using $\mathrm{PEG}$, shows a single-stage uniform mass loss. The mass loss in the decomposition from room temperature to $420^{\circ} \mathrm{C}$ is $29.6 \%$. This mass loss is due to the evaporation of water on the surface of the material, decomposition of the oxalic acid and $\mathrm{SnCl}_{2}$ as well as the PEG. It has been reported that PEG starts

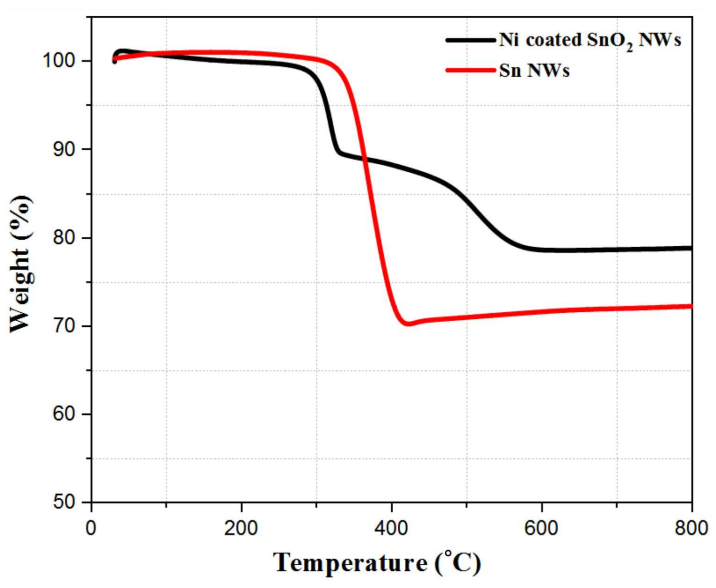

Fig. 1. TGA thermogram of $\mathrm{Sn}$ and $\mathrm{Ni} / \mathrm{SnO}_{2}$ nanowires.

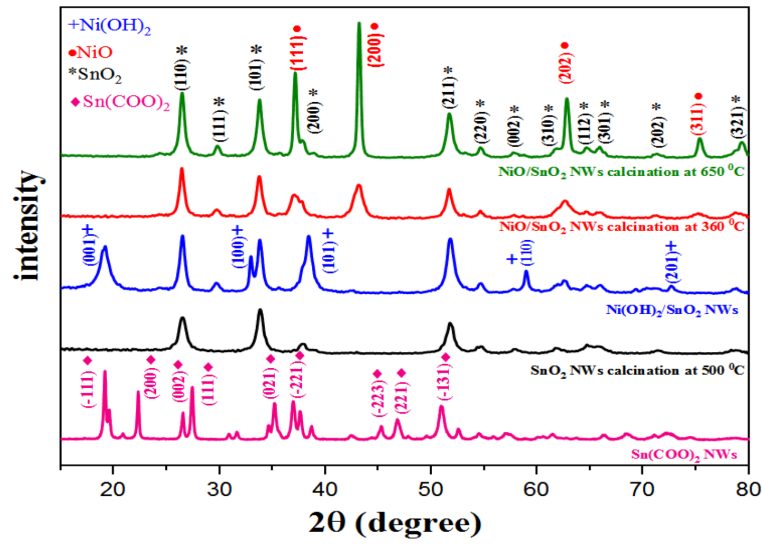

Fig. 2. XRD pattern of Sn-based and $\mathrm{NiO} / \mathrm{SnO}_{2} \mathrm{NWs}$ at different calcination temperature.

to decompose at $340^{\circ} \mathrm{C}$ and its degradation has ended at $415^{\circ} \mathrm{C}$ with its mass loss being approximately $99 \%$ [42]. It can be said that the $\mathrm{Sn}(\mathrm{COO})_{2}$ structure is completely converted to $\mathrm{SnO}_{2}$ after $420^{\circ} \mathrm{C}$. This result was also supported by XRD measurements (Fig. 2). In the region up to $420^{\circ} \mathrm{C}$, it can be said that the polymer chains in PEG are thermally degraded and the mass loss of $29.6 \%$ belongs to $\mathrm{Sn}$ nanowires.

TGA analysis of the Ni-coated $\mathrm{SnO}_{2}$ nanowires shows that mass loss occurs in three different temperature zones. In the first region $\left(30-150^{\circ} \mathrm{C}\right), 1.3 \%$ mass loss can be attributed to the removal of moisture in the structure and $10 \%$ mass loss in the $150{ }^{\circ} \mathrm{C}-330^{\circ} \mathrm{C}$ range can be attributed to the continuous disposal of water and ethanol from the sample [43]. The mass loss of $12 \%$ in the $330{ }^{\circ} \mathrm{C}-600{ }^{\circ} \mathrm{C}$ temperature range suggested that dehydration of surface hydroxyl groups took place. In this region, the $\mathrm{Ni}(\mathrm{OH})_{2} / \mathrm{SnO}_{2}$ structure was completely transformed into $\mathrm{NiO} / \mathrm{SnO}_{2}$. Above $600^{\circ} \mathrm{C}$, no significant mass loss occurred and $77 \%$ of the material remained. 

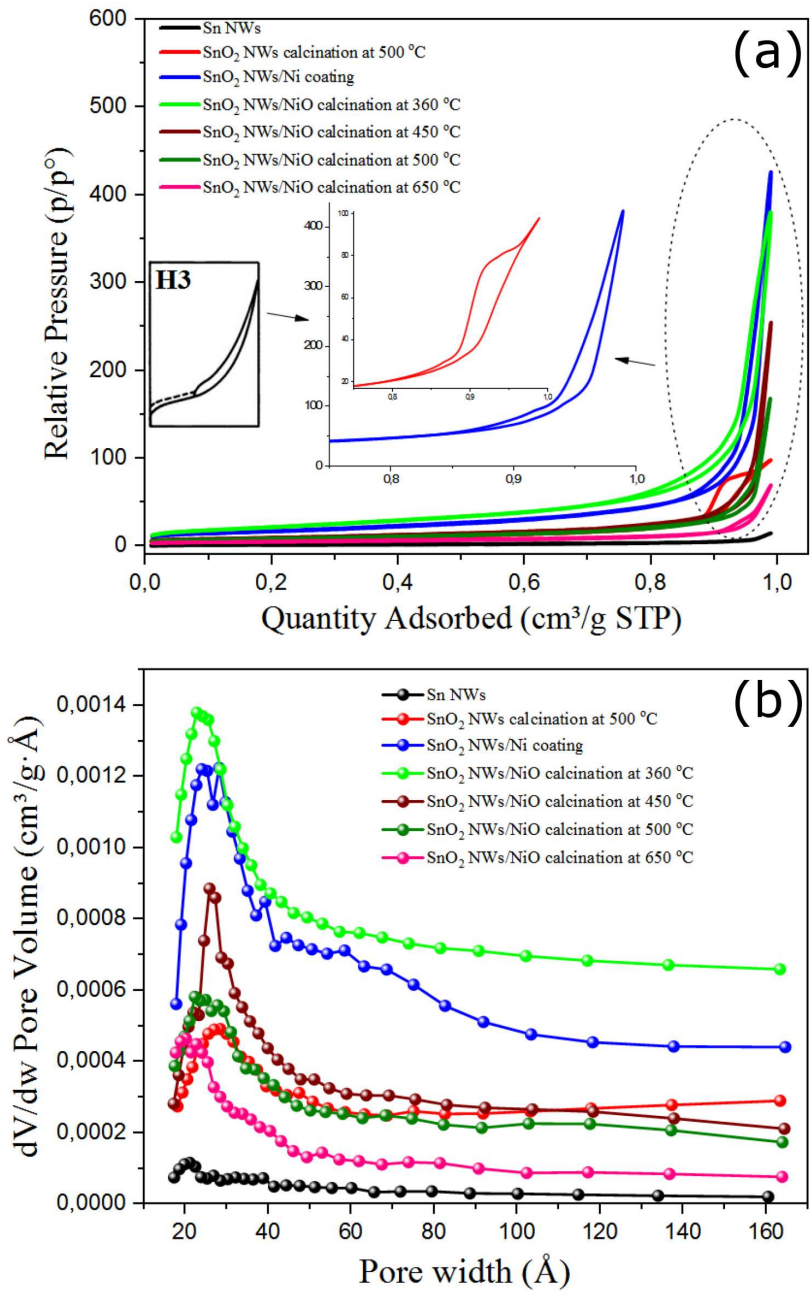

Fig. 3. (a) Nitrogen adsorption-desorption isotherm of $\mathrm{SnO}_{2}$ and $\mathrm{NiO} / \mathrm{SnO}_{2} \mathrm{NWs}$ at different calcination temperature. Inset shows the zoom of hysteresis area in nitrogen adsorption-desorption isotherm. (b) BJH pore size distribution.

Figure 3a shows $\mathrm{N}_{2}$ adsorption-desorption curves of the $\mathrm{SnO}_{2}$ and $\mathrm{NiO} / \mathrm{SnO}_{2}$ nanowires. While the BET surface area of the $\mathrm{Sn}(\mathrm{COO})_{2}$ nanowires was $5.74 \mathrm{~m}^{2} / \mathrm{g}$, it was increased to $25.39 \mathrm{~m}^{2} / \mathrm{g}$ for the $\mathrm{SnO}_{2}$ nanostructures after heat treatment at $500{ }^{\circ} \mathrm{C}$. The nickel plating of $\mathrm{SnO}_{2}$ nanowires increased the BET surface area to $62.05 \mathrm{~m}^{2} / \mathrm{g}$. The BET surface areas of the heat-treated samples at $360,450,500$, and $650{ }^{\circ} \mathrm{C}$ were $79.75,33.38,29.15$, and $21.13 \mathrm{~m}^{2} / \mathrm{g}$, respectively. The adsorption isotherm, where micro $(<2 \mathrm{~nm})$ and mesopores $(2-50 \mathrm{~nm})$ coexist (Fig. $3 \mathrm{~b})$ (according to the classification of the IUPAC), is known as type IV [44]. The nitrogen adsorption-desorption curves (Fig. 3a) are in good agreement with type IV isotherm, which exhibits a similar hysteresis H3 [44] curve seen in the pores formed by plane-like particles. XRD graphs of the materials containing $\mathrm{Sn}$ and $\mathrm{Ni}-\mathrm{Sn}$ nanowires are given in Fig. 3 .
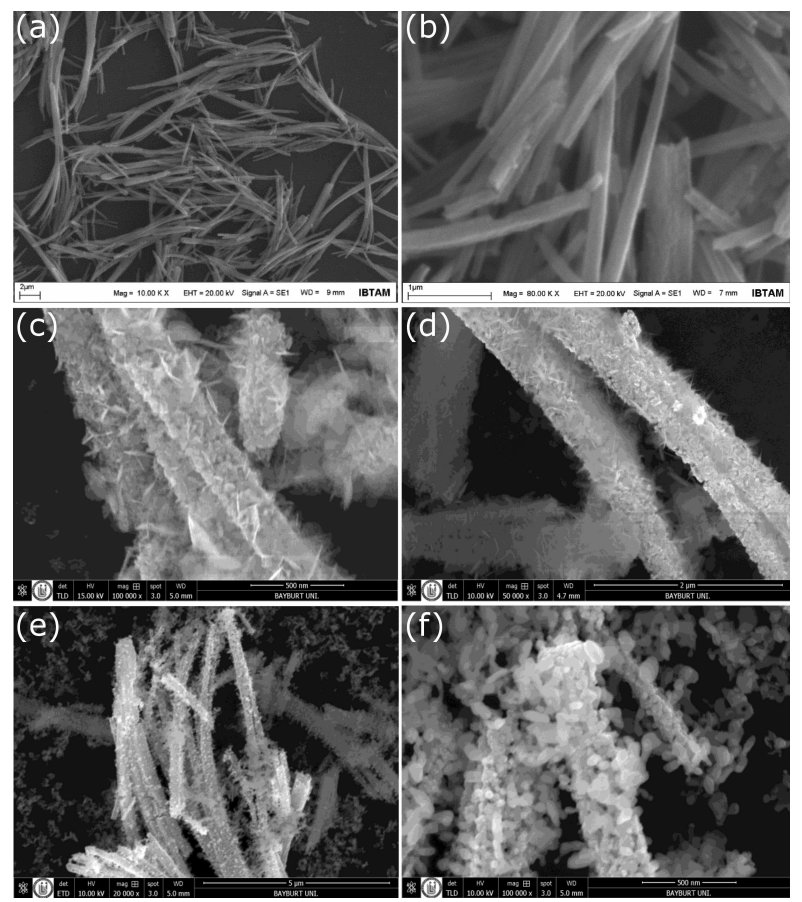

Fig. 4. SEM images of (a, b) $\mathrm{SnO}_{2} \mathrm{NWs,} \mathrm{(c,} \mathrm{d)}$ $\mathrm{NiO} / \mathrm{SnO}_{2} \mathrm{NWs}$ calcined at $360^{\circ} \mathrm{C}$, (e, f) $\mathrm{NiO} / \mathrm{SnO}_{2}$ NWs calcined at $650^{\circ} \mathrm{C}$

In the nanowires produced using PEG, only the peaks of the (-111), (200), (002), (111), (021), (-221), (-223), $(221)$, and $(-131)$ planes of the $\mathrm{Sn}(\mathrm{COO})_{2}$ structure were observed before the heat treatment. It was also found that the heat-treated sample at $500{ }^{\circ} \mathrm{C}$ is in the tetragonal rutile $\mathrm{SnO}_{2}$ phase given by PDF \# 41-1445 card number. The observed diffraction patterns at $26.5^{\circ}, 33.8^{\circ}, 37.8^{\circ}$, $51.7^{\circ}, 54.7^{\circ}, 57.9^{\circ}, 61.7^{\circ}, 64.7^{\circ}, 65.8^{\circ}, 71.3^{\circ}$, and $79.3^{\circ}$ correspond to the planes of (110), (101), (200), (211), (220), (002), (310), (112), (301), (202), and (321), respectively. In the XRD analysis of the material formed by precipitation of $\mathrm{Ni}^{2+}$ ions by $\mathrm{NH}_{4} \mathrm{OH}$ on $\mathrm{SnO}_{2}$ nanowires, in addition to the peaks of $\mathrm{SnO}_{2}$, peaks corresponding to the planes (001), (100), (101), (110), (201) were observed at the angle values of $19.25^{\circ}, 33.06^{\circ}, 38.54^{\circ}, 59.05^{\circ}$, and $72.7^{\circ}$, respectively. It was seen that this result matches with the $\mathrm{Ni}(\mathrm{OH})_{2}$ structure given by the PDF \#14-0117 card number. In the material heat treated at $360^{\circ} \mathrm{C}$ and $650^{\circ} \mathrm{C}$, besides the peaks of $\mathrm{SnO}_{2}$, peaks belonging to planes (111), (200), (220), and (311) were observed at angles of $37.24^{\circ}, 43.27^{\circ}, 62.87^{\circ}$, and $75.41^{\circ}$, which are thought to belong to $\mathrm{NiO}$. The structure matches with the face-centred cubic NiO phase given by the card number PDF \# 47-1049.

Park et al. [45] have shown that the $\mathrm{NiO}$ phase forms at temperatures higher than $300^{\circ} \mathrm{C}$. This result has a very good agreement with the present study. The material containing $\mathrm{NiO} / \mathrm{SnO}_{2}$ nanowires heat-treated at $650{ }^{\circ} \mathrm{C}$ exhibited sharper diffraction peaks than the heat-treated sample at $360^{\circ} \mathrm{C}$. According to this, the crystallinity of the heat-treated hybrid material at $650^{\circ} \mathrm{C}$ is better. 

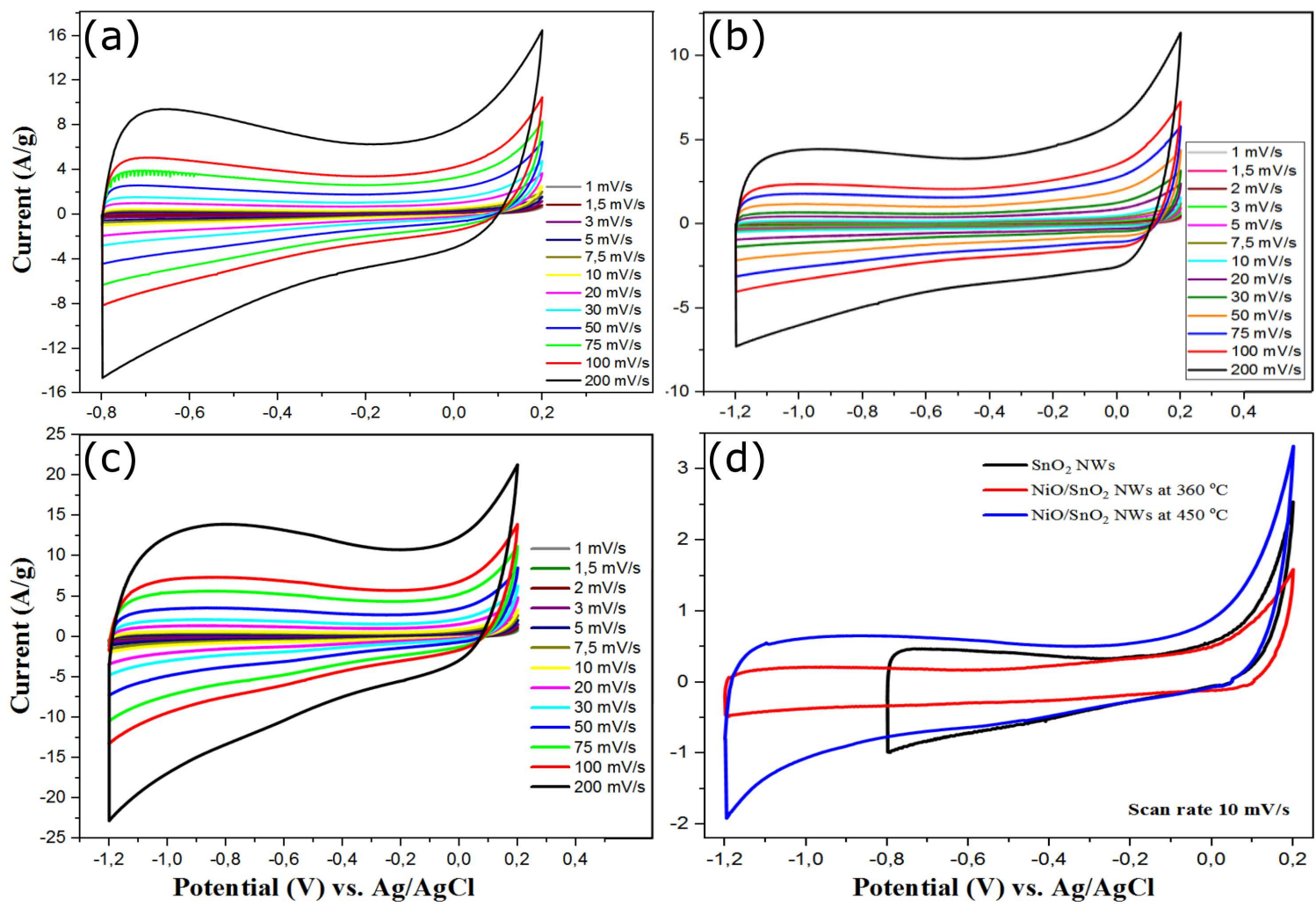

Fig. 5. CV curves of (a) $\mathrm{SnO}_{2} \mathrm{NWs}$, (b) $\mathrm{NiO} / \mathrm{SnO}_{2} \mathrm{NWs}$ calcined at $360^{\circ} \mathrm{C}$, (c) $\mathrm{NiO} / \mathrm{SnO}_{2} \mathrm{NWs}$ calcined at $450{ }^{\circ} \mathrm{C}$, (d) comparison of $\mathrm{CV}$ curves at a scan rate of $10 \mathrm{mV} / \mathrm{s}$.

Figure 4 shows the SEM images of the $\mathrm{SnO}_{2}$ and $\mathrm{NiO} / \mathrm{SnO}_{2}$ nanowires at different magnifications. It can be seen that the $\mathrm{SnO}_{2}$ nanowires, heat treated at $500^{\circ} \mathrm{C}$, have diameters ranging from 100 to $250 \mathrm{~nm}$ and also vary in size from 6 to $10 \mu \mathrm{m}$ (Fig. 4a and b). Figure $4 \mathrm{c}$ and d shows SEM images of $\mathrm{NiO} / \mathrm{SnO}_{2}$ hybrid nanowires heattreated at $360^{\circ} \mathrm{C}$. The presence of $\mathrm{NiO}$ leafy structures on $\mathrm{SnO}_{2}$ nanowires can be seen. The NiO leafy structure grew homogeneously throughout the nanowires. The $\mathrm{H} 3$ hysteresis observed in the $\mathrm{N}_{2}$ adsorptiondesorption isotherm curves, originates from the $\mathrm{NiO}$ leafy structure.

Also, the leafy shape $\mathrm{NiO}$ structures on the nanowires are the reason for the increase in the BET surface area. The $\mathrm{NiO}$ leafy structure on $\mathrm{SnO}_{2}$ nanowires has changed to a more spherical structure (Fig. 4e and f) as a result of increase of the heat treatment temperature to $650^{\circ} \mathrm{C}$. The transformation of the $\mathrm{NiO}$ leaf structure into a spherical shape explains the decrease in the BET surface area. Cyclic voltammetry (CV) is one of the important methods used in the investigation of electrochemical properties. The electrochemical performance of electrodes containing $\mathrm{SnO}_{2}$ and $\mathrm{NiO} / \mathrm{SnO}_{2}$ nanowires was investigated using a three-electrode cell in $6 \mathrm{M} \mathrm{KOH}$. In particular, electrodes containing $\mathrm{NiO} / \mathrm{SnO}_{2}$ nanowires showed a rectangular shape similar to the CV curve of the ideal supercapacitor (Fig. 5). As the heat treatment temperature increased, a noticeable increase was observed in the area under the curve. It can be seen that the working potential window of the $\mathrm{SnO}_{2}$ electrode, in the range of $-0.8 \mathrm{~V}$ to $0.2 \mathrm{~V}$, is extended to the range of $-1.2 \mathrm{~V}$ to $0.2 \mathrm{~V}$ by the addition of $\mathrm{NiO}$ to the structure (Fig. $5 \mathrm{~d}$ ).

Typically, specific capacitance $(C)$ is used to characterize the performance of electrode material. Figure 6 shows the specific capacitance changes calculated from the long-term charge-discharge curves for the different electrodes. The specific capacitance is also evaluated according to the following equation [43]:

$$
C=\frac{I \Delta t}{m \Delta V},
$$

where $I$ is the discharge current, $\Delta t$ is the discharge time, $\Delta V$ is the potential window, and $m$ is the mass of nanowires. All of the electrodes were chargeddischarged for at least 3000 cycles at $1 \mathrm{~A} / \mathrm{g}$. The specific capacitance of the electrode containing only $\mathrm{SnO}_{2}$ nanowires was approximately $60 \mathrm{~F} / \mathrm{g}$ and no significant loss of capacitance was observed with long-term chargedischarge measurements. Among the electrodes containing $\mathrm{NiO} / \mathrm{SnO}_{2}$ nanowires, the best electrochemical performance was shown by the electrode heat treated at $450^{\circ} \mathrm{C}$. The initially observed specific capacitance was $\approx 143 \mathrm{~F} / \mathrm{g}$. After 400 continuous charge-discharge cycles the specific capacitance decreased to $130 \mathrm{~F} / \mathrm{g}$ and continued to charge-discharge stably for 3000 cycles. 

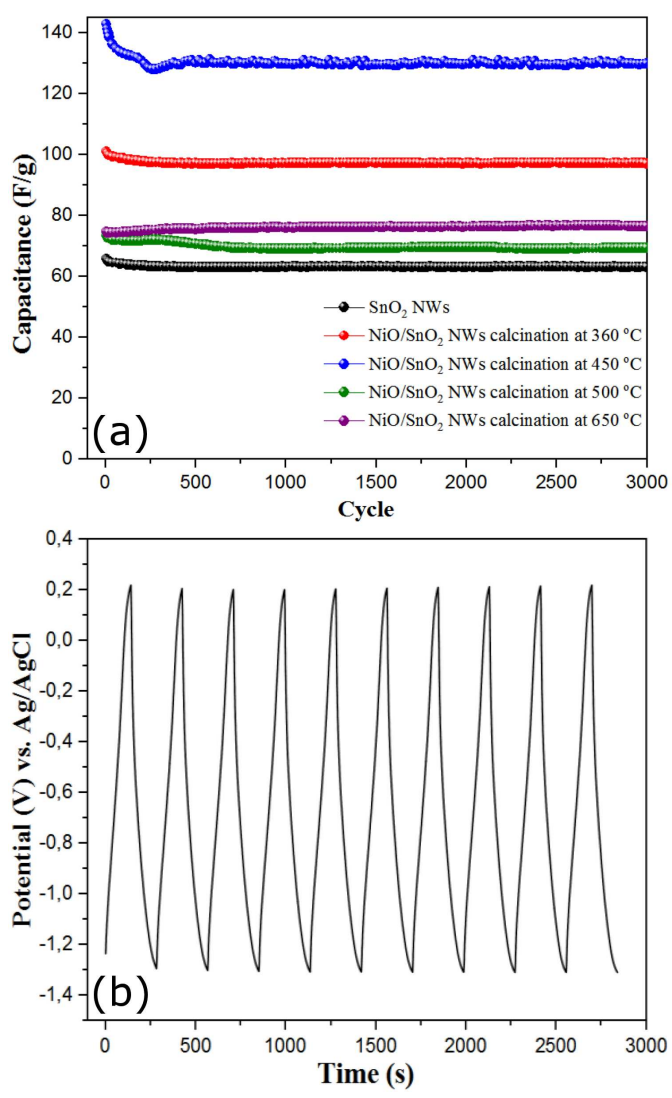

Fig. 6. (a) Variation of capacitance as a function of cycle number of $\mathrm{SnO}_{2}$ and $\mathrm{NiO} / \mathrm{SnO}_{2}$ NWs at different calcination temperature. (b) The first ten cyclic charge-discharge curves of $\mathrm{NiO} / \mathrm{SnO}_{2} \mathrm{NWs}$ calcination at $450^{\circ} \mathrm{C}$.

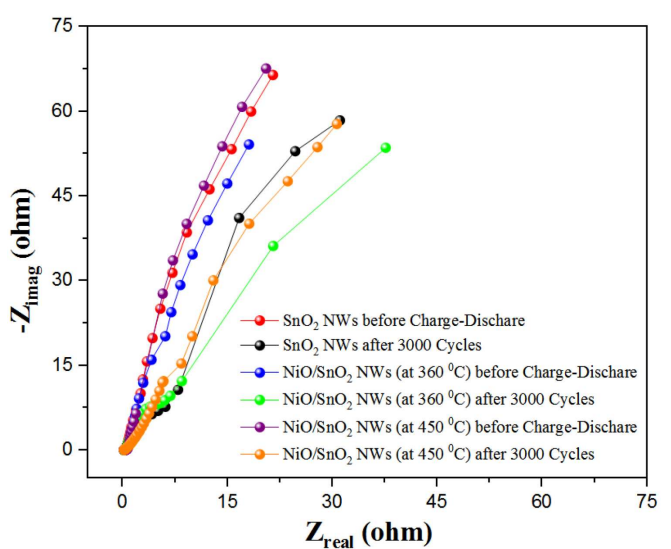

Fig. 7. Nyquist plots of $\mathrm{SnO}_{2}$ and $\mathrm{NiO} / \mathrm{SnO}_{2}$ NWs at different calcination temperature at open circuit potential.

Figure 7 shows the Nyquist curves that were taken immediately after the CV measurements and after 3000 continuous charge-discharge cycles. The slope of the linear curve in the middle frequency region, for all electrodes, is greater than $45^{\circ}$, which is a good indicator for the generated supercapacitor electrodes. In general, the decrease in electrode performance after prolonged chargedischarge cycles is manifested by a decrease in the theta $(\theta)$ value. This diminution amount is a minimum for the $\mathrm{NiO} / \mathrm{SnO}_{2} \mathrm{NW}$ electrode, especially obtained at $450^{\circ} \mathrm{C}$, with a decrease from $75^{\circ}$ to $67^{\circ}$ being observed.

\section{Conclusions}

In this study, $\mathrm{SnO}_{2}$ material was produced in nanowire form in a very short time and by an inexpensive method which takes advantage of PEG's one-way chain growth. It was also found that the electrodes with $\mathrm{NiO} / \mathrm{SnO}_{2}$ structure are very important in terms of energy density since they have a much wider operating potential range than $\mathrm{SnO}_{2}$ electrodes, and many electrodes in the literature. Electrochemical tests also showed that the $\mathrm{NiO} / \mathrm{SnO}_{2}$ electrode, heat-treated at $450^{\circ} \mathrm{C}$, has the best performance. This is thought to result from the leafy $\mathrm{NiO}$ structures on the $\mathrm{SnO}_{2}$ nanowire surface.

\section{Acknowledgments}

This work was supported by Inonu University with the project numbers I.U.FLY-2018-1268 and I.U.2015/67.

\section{References}

[1] M.A.A.M. Abdah, N.H.N. Azman, S. Kulandaivalu, Y. Sulaiman, Mater. Des. 186, 108199 (2019).

[2] X. Shi, S. Zheng, Z.S. Wu, X. Bao, J. Energy Chem. 27, 25 (2018).

[3] Z.S. Iro, C. Subramani, S.S. Dash, Int. J. Electrochem. Sci. 11, 10628 (2016).

[4] K. Wu, J. Zhao, X. Zhang, H. Zhou, M. Wu, J. Taiwan Instit. Chem. Eng. 102, 212 (2019).

[5] W. Wu, D. Niu, J. Zhu, et al., Ceram. Int. 45, 16261 (2019).

[6] R. Atchudan, T.N.J.I. Edison, S. Perumal, P. Thirukumaran, R. Vinodh, Y.R. Lee, J. Taiwan Instit. Chem. Eng. 102, 475 (2019).

[7] A. Afif, S.M.H. Rahman, A.T. Azad, J. Zaini, M.A. Islan, A.K. Azad, J. Energy Storage 25, 100852 (2019).

[8] A. Queraltó, A. Pérezdel Pino, C. Logofatu, A. Datcu, R. Amade, E. Bertran-Serra, E. György, Ceram. Int. 44, 20409 (2018).

[9] P. Pascariu, A. Airinei, N. Olaru, I. Petrila, V. Nica, L. Sacarescu, F. Tudorache, Sens. Actuat. B 222, 1024 (2016)

[10] J. Zhang, Y. Sun, J. Xu, Micro Nano Lett. 14, 254 (2019).

[11] Y.R. Ahn, M.Y. Song, S.M. Jo, C.R. Park, D.Y. Kim, Nanotechnology 17, 2865 (2006).

[12] C.C. Hu, Y.H. Huang, K.H. Chang, J. Power Sourc. 108, 117 (2002).

[13] F.E. Atalay, D. Asma, H. Kaya, E. Ozbey, Mater. Sci. Semicond. Process. 38, 314 (2015). 
[14] J. Yan, T. Wei, J. Cheng, Z. Fan, M. Zhang, Mater. Res. Bull. 45, 210 (2010).

[15] J. Jiang, A. Kucernak, Electrochim. Acta 47, 2381 (2002).

[16] V.D. Patake, C.D. Lokhande, O.S. Joo, Appl. Surf. Sci. 255, 4192 (2009).

[17] F.E. Atalay, H. Kaya, D. Asma, A. Bingöl, Biointerface Res. Appl. Chem. 6, 1099 (2016).

[18] S.G. Kandalkar, J.L. Gunjakar, C.D. Lokhande, Appl. Surf. Sci. 254, 5540 (2008).

[19] U.M. Patil, R.R. Salunkhe, K.V. Gurav, C.D. Lokhande, Appl. Surf. Sci. 255, 2603 (2008).

[20] P.A. Nelson, J.R. Owen, J. Electrochem. Soc. 150 , A1313 (2003)

[21] N. Miura, S. Oonishi, K.R. Prasad, Electrochem. Solid State Lett. 7, A247 (2004).

[22] C.C. Hu, C.M. Huang, K.H. Chang, J. Power Sources 185, 1594 (2008).

[23] M. Nakayama, A. Tanaka, Y. Sato, T. Tonosaki, K. Ogura, Langmuir 21, 5907 (2005).

[24] D.L. da Silva, R.G. Delatorre, G. Pattanaik, G. Zangari, W. Figueiredo, R.-P. Blum, H. Niehus, A.A. Pasal, J. Electrochem. Soc. 155, E14 (2008).

[25] X. Zhou, H. Chen, D. Shu, C. He, J. Nan, J. Phys. Chem. Solids 70, 495 (2009).

[26] B. Babakhani, D.G. Ivey, J. Power Sourc. 195, 2110 (2010).

[27] D. Dodoo-Arhina, R.A. Nuamaha, P.K. Jainb D.O. Obada, A. Yaya, Results Phys. 9, 1391 (2018).

[28] S. Das, V. Jayaraman, Progr. Mater. Sci. 66, 112 (2014).

[29] J. Liu, Y. Li, X. Huang, R. Ding, Y. Hu, J. Jiang, L. Liao, J. Mater. Chem. 19, 1859 (2009).
[30] J.H. Shin, H.M. Park, J.Y. Song, J. Alloys Comp. 551, 451 (2013).

[31] H.J. Snaith, C. Ducati, Nano Lett. 10, 1259 (2010).

[32] H.W. Song, N. Li, H. Cui, C.X. Wang, J. Mater. Chem. A 1, 7558 (2013).

[33] R.B. Rakhi, W. Chen, D. Cha, H.N. Alshareef, J. Mater. Chem. 21, 16197 (2011).

[34] A.A. Firooz, A.R. Mahjoub, A.A. Khodadadi, Sens. Actuat. B 141, 89 (2009).

[35] G.F. Xia, N. Li, D.Y. Li, R.Q. Liu, N. Xiao, D. Tian, Mater. Lett. 65, 3377 (2011).

[36] Y. Chen, Q.Z. Huang, J. Wang, Q. Wang, J.M. Xue, J. Mater. Chem. 21, 17448 (2011)

[37] F. Pourfayaz, A. Khodadadi, Y. Mortazavi, S.S. Mohajerzadeh, Sens. Actuat. B 108, 172 (2005).

[38] H. Cui, Y. Liu, W. Ren, M. Wang, Y. Zhao, Nanotechnology 24, 345602 (2013).

[39] Y.X. Yin, L.Y. Jiang, L.J. Wan, C.J. Li, Y.G. Guo, Nanoscale 3, 1802 (2011).

[40] M. Zhao, Q. Zhao, J. Qiu, H. Xuea, H. Pang, $R S C$ Adv. 6, 95449 (2016).

[41] S. Ren, Y. Yang, M. Xu, H. Cai, C. Hao, X. Wang, Coll. Surf. A 444, 26 (2014)

[42] S.K. Kwon, D.H. Kim, J. Korean Phys. Soc. 49, 1421 (2006).

[43] F.E. Atalay, D. Asma, H. Kaya, A. Bingol, P. Yaya, Nanomater. Nanotechnol. 6, 1 (2016).

[44] K.S.W. Sing, D.H. Everett, R.A.W. Haul, L. Moscou, R.A. Pierotti, J. Rouquerol, T. Siemieniewska, Pure Appl. Chem. 57, 603 (1985).

[45] J.Y. Park, S.W. Choi, S.H. Jung, S.S. Kim, J. Nanosci. Nanotechnol. 12, 1288 (2012). 